\title{
NATURAL HISTORY NOTE \\ First record of tree cavity roosting in frosted myotis (Myotis pruinosus)
}

\author{
Vladimir Dinets ${ }^{1,2^{*}}$
}

\author{
${ }^{1}$ Okinawa Institute of Science and \\ Technology, Onna-son, Okinawa, Japan \\ 2 Biology Dept., University of Tennessee, \\ Knoxville, Tennessee, USA \\ *Corresponding author: \\ dinets@gmail.com \\ DOI: https://doi.org/10.14709/ \\ BarbJ.13.1.2020.02 \\ Keywords: Japan, Japanese pygmy \\ woodpecker, Nikko National Park, \\ Picoides kizuki, summer roost
}

received: November, 8th 2019 accepted: February, 25th 2020

\begin{abstract}
Frosted myotis (Myotis pruinosus) is a rare and little-known bat, listed as Endangered by the IUCN. Although it inhabits forests and has been suspected to roost in tree cavities, all roosting individuals found to date were in caves. Hereby, I report a discovery of an individual roosting in a tree cavity made by Japanese pygmy woodpecker (Picoides kizuki), in a large pine tree in an old-growth mixed forest in Nikko National Park, Japan. This observation confirms that frosted myotis roosts in tree cavities but does not support the hypothesis that dependence on larger cavities explains the species' affinity with old-growth forests.
\end{abstract}

Frosted myotis (Myotis pruinosus Yoshiyuki, 1971) is a rare and little-known bat endemic to Japanese islands of Honshu, Shikoku and Kyushu (Kawai 2015) and listed as Endangered by the IUCN Red List (Fukui \& Sano 2019b). It is known only from old-growth forests (Abe et al. 2005). Although the only roosting individuals ever found were in caves (Kawai 2015), such findings are extremely rare, so this species has been suspected to mostly roost in tree cavities (Abe et al. 2005), like the closely related Yanbaru myotis ( $M$. yanbarensis) of Ryukyu Islands (Fukui \& Sano 2019a).

On 26 June 2019, near midnight, on an overcast night with light drizzle and air temperatures of $6-9^{\circ} \mathrm{C}$, a bat (Fig. 1) was found roosting in a tree, in Yu river valley in Nikko National Park, Japan, at 36 $47^{\prime} 14^{\prime \prime} \mathrm{N}, 129^{\circ} 26^{\prime} 00^{\prime \prime} \mathrm{E}$, at $\sim 1420$ $\mathrm{m}$ a. s. I. The bat was at the entrance of a cavity in a pine (possibly Pinus parviflora) $\sim 2 \mathrm{~m}$ above ground. The tree, $\sim 50 \mathrm{~cm}$ in diameter at the height of the cavity, was $\sim 5 \mathrm{~m}$ from a small river, in an old growth mixed forest dominated by Nikko fir (Abies homolepis), Mongolian oak (Quercus mongolica var. grosseserrata) and Japanese elm (Ulmus davidiana var. japonica) (Yoshikura et al. 2011). The forest was logged during the Edo Period (1603-1868) and has been protected within Nikko National Park since 1934 (Shen et al. 2013). The cavity, with circular entrance $40-45 \mathrm{~mm}$ in diameter, was a typical abandoned nest cavity of Japanese pygmy woodpecker (Picoides kizuki), a common bird in the area and the only bird in Japan known to excavate cavities of such small diameter in living trees (Winckler \& Christie 2002, Gorman 2014). There were no visible droppings on the ground underneath the cavity. The bottom part of the cavity was not visible from the outside, but the odor at the cavity entrance was typical for long-used bat roosts and suggested presence of feces inside.
The bat was first found using Pulsar Quantum Lite XQ30V thermal scope, then observed using red flashlight and photographed using Sony RX-10 IV digital camera with Sony HVL-F60M external flash (Fig. 1). After the first camera flash it flew away. The bat's tiny size (head width $<2.5 \mathrm{~cm}$, estimated from the photo by comparison with the diameter of the cavity), black fur with whitish tips ("frosted" appearance), and relatively short tragus allowed it to be confidently identified as M. pruinosus (see Abe et al. 2005), very similar in appearance to $M$. yanbarensis (closely related but endemic to the Ryukyu Islands) which the observer had seen in hand and in a roost. Other small bats of central Honshu have brown rather than black fur, except for some individuals of Eastern long-fingered myotis ( $M$. macrodactylus), which is larger, with pale underparts including chin and throat, and roosts in caves, stone structures, and burrows in riverbanks (Abe et al. 2005, Sano 2015). Previous survey of the area did not detect $M$. pruinosus (Yoshikura et al. 2011), although there are records from other parts of Nikko National Park, including Yunishigawa area $15-20 \mathrm{~km}$ to the northeast (Koyanagi 2011).

This observation confirms the suggestion (Abe et al. 2005) that $M$. pruinosus uses tree cavities as roosts. Dependence of tree cavities has been said to explain its rarity and affinity with old-growth forests (Abe et al. 2005, Fukui \& Sano 2019a). However, small cavities like the one described above can also be found in young forests, where Japanese pygmy woodpecker is also common (Winckler \& Christie 2002). There is a possibility that $M$. pruinosus can use small cavities for night roosts but needs larger ones for day roosts; however, no such difference in cavity size between night and day roosts has been reported for any Myotis (see Moratelli \& Burgin 2019 and bibliography therein). Another possibility is that larger cavities are needed only for maternity roosts. 

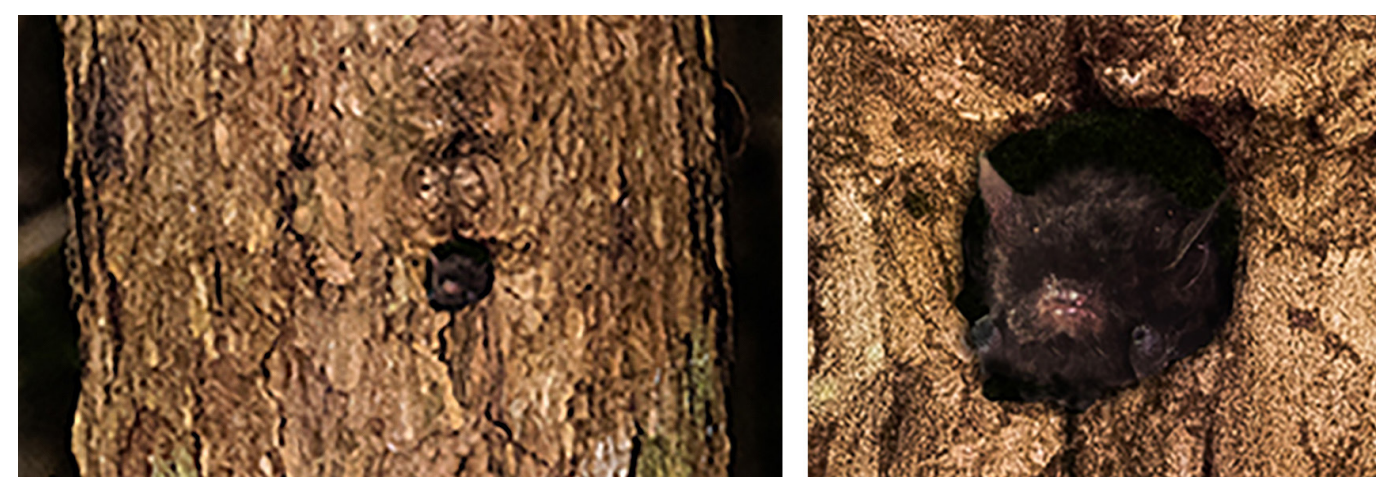

Fig. 1 - A frosted myotis (Myotis pruinosus) in a cavity excavated by Japanese pygmy woodpecker (Picoides kizuki), in Nikko National Park, Japan.

Old-growth forests are now widely distributed in many parts of Japan (Dauvergne 1997), so the rarity of M. pruinosus cannot be explained by its dependence on such habitat. It is noteworthy that the closely related $M$. yanbarensis roosts in small tree cavities in densely forested river valleys, and occupies only a small portion of seemingly appropriate habitat within its range (Fukui \& Sano 2019b, Jason Preble pers. comm.; also pers. obs. by the author). Apparently, the reasons for these species' habitat specialization are yet to be elucidated; they might include intraspecific competition, dependence on particular prey items or macroclimatic conditions, as well as differences in canopy/subcanopy structure and predation pressure (Patriquin \& Barclay 2003, Loeb \& O’Keefe 2006, Jung et al. 2012).

\section{ACKNOWLEDGMENTS}

I thank Jane Coldwell and the anonymous reviewers for editorial comments, and Jason Preble (University of Kyoto) for sharing his unpublished data and helping me in obtaining first-hand field experience with Yanbaru myotis.

\section{REFERENCES}

ABE, H., ISHII, N., ITOO, T., KANEKO, Y., MAEDA, K., MIURA, S. \& YONEDA, M. (2005). A Guide to the Mammals of Japan. ed.: Tokai University Press. Kanagawa, Japan, 206 pp.

DAUVERGNE, P. (1997). Shadows in the forest: Japan and the politics of timber in Southeast Asia. ed.: The MIT Press. Cambridge, Massachusetts, 320 pp.

FUKUI, D. \& SANO, A. (2019a). Myotis pruinosus. The IUCN Red List of Threatened Species. 2019: e.T14192A22066846. https://doi.org/10.2305/IUCN. UK.2019-3.RLTS.T14192A22066846.en

FUKUI, D. \& SANO, A. (2019b). Myotis yanbarensis. The IUCN Red List of Threatened Species. 2019: e.T29484A22067327. https://doi.org/10.2305/IUCN. UK.2019-3.RLTS.T29484A22067327.en

GORMAN, G. (2014). Woodpeckers of the World: a Complete Guide. Helm Photographic Guides. ed.: Bloomsbury Publishing PLC. London, United Kingdom, 528 pp.
JUNG, K., KAISER, S., BÖHM, S., NIESCHULZE, J. \& KALKO, E. K. V. (2012). Moving in three dimensions: effects of structural complexity on occurrence and activity of insectivorous bats in managed forest stands. Journal of Applied Ecology, 49(2): 523-531. https://doi. org/10.1111/j.1365-2664.2012.02116.x

KAWAI, K. (2015). Myotis pruinosus (Yoshiyuki, 1971). In: Wild Mammals of Japan. ed.: Shoukadoh Book Sellers and Mammal Society of Japan. Kyoto, Japan, p.114-115.

KOYANAGI, K. (2011). Bat fauna of Yunishigawa area in Nikko, Tochigi Prefecture. Bulletin of Tochigi Prefectural Museum, 28: 1-4 (in Japanese with English abstract).

LOEB, S. C. \& O'KEEFE, J. M. (2006). Habitat use by forest bats in South Carolina in relation to local, stand, and landscape characteristics. The Journal of Wildlife Management, 70(5): 1210-1218. https://doi.org/10.2193/0022-541X(2 006)70[1210:HUBFBI]2.0.CO;2

MORATELLI, R. \& BURGIN, C. (2019). Family Vespertilionidae (Vesper Bats). In: Handbook of the Mammals of the World. Vol. 9. Bats. ed.: Wilson, D. E. \& Mittermeier, R. A. Barcelona, Spain, p.716-982.

PATRIQUIN, K. J. \& BARCLAY, R. M. R. (2003). Foraging by bats in cleared, thinned and unharvested boreal forest. Journal of Applied Ecology, 40(4): 646-657. https://doi. org/10.1046/j.1365-2664.2003.00831.x

SANO, A. (2015). Myotis macrodactylus (Temminck, 1840). In: Wild Mammals of Japan. ed.: Shoukadoh Book Sellers and Mammal Society of Japan. Kyoto, Japan, p.107-109.

SHEN, G., SAKAI, K. \& KAJI, K. (2013). Capturing landscape changes and ecological processes in Nikko National Park (Japan) by integrated use of remote sensing images. Landscape Ecol Eng, 9: 89-98. https://doi.org/10.1007/ s11355-011-0180-1

WINCKLER, H. \& CHRISTIE, D. A. (2002). Family Picidae (Woodpeckers). In: Handbook of the Birds of the World. Vol. 7. Jacamars to Woodpeckers. ed.: del Hoyo, J., Elliot, A. \& Sargatal, J. Barcelona, Spain, p.296-555.

YOSHIKURA, S., YASUI, S. \& KAMIJO, T. (2011). Comparative study of forest-dwelling bats' abundances and species richness between old-growth forests and conifer plantations in Nikko National Park, Central Japan. Mammal Study, 36(4): 189-199. https://doi. org/10.3106/041.036.0402 